\title{
Difficulties and Problems that Face English Students ofAl Quds Open University in Cultural Translation process from English toArabic and vice versa and the solutions for the Same
}

\author{
By Dr. Ahmed Maher Mahmoud Al Nakhal
}

\section{INTRODUCTION}

Communication between cultures canbe achieved through translation. Through translation, people areintroduced to different languages and ways of thought. It is important to understand the relation between language and culture in order to train translators and interpreters. "What truly distinguishes translation is that it takes place in the context of the relations between two cultures, two worlds of thought and perception" (Delisle 1988, 74). Newmark (1981, 183-185) argues that there is a cultural value in translation. Language is partly the reflection of a culture. Translators like linguists tend to define culture as the sum of people's customs and ways of thinking. Culture is heavily indebted for its intellectual development to translation. Nothing demonstrates the complexity of language and of specific texts more vividly and explicitly than translation. Further, nothing exposes good writing and bad writing as effectively as translation. Translation is important as a source of diffusion of knowledge of every kind. By understanding the development of every aspect of culture in other civilizations, people can also enrich their understanding of their own culture. Knowledge of the target culture is crucial for successful English-Arabic translation. Poor comprehension may arise from lack of insight into the target culture. There is a mismatch in cultural norms and beliefs between the Arab and Western cultures. Each different language has its own individuality, which makes it distinctive and peculiar to the people who speak it. Words denote things and put them in a distinct category of thought. As a result, differences between languages are not only related to the linguistic system, but involve differences in the speakers' interpretation and understanding of the world they live in. Languages classify knowledge in various ways for the purposes of speech.(Roxana Mareş-2012)In studying the language of a society of better to say country, it is not a good idea to focus just on the language and the process ofcommunication. Indeed there are other structures that help us better in understanding a country more than language. One of these structures can be regarded as culture. In this way knowing about the culture of a society takes us beyond our purpose. We know that a nation's culture flourishes by interacting with other cultures. Cultural variety opens our eyes to human rights, but cultural variety can only be recognized through discussions. Generally, Language is an expression of culture and individuality of its speakers. It influences the way the speakers perceive the world. So focusing on the issue of translation from one language to another, the culture of both languages in the process of translation is influential. Of course one should consider that to what extent the culture is in the text and to what extent the language is in culture.(Akbari-2013)As a matter of fact, a good translator should be familiar with the culture, customs, and social settings of the source and target language speakers. He should also be familiar with different styles of speaking, and social norms of both languages. This awareness, can improve the quality of the translations to a great extent. According to Hatim and Mason (1990), the social context in translating a text is probably a more important variable than its genre. The act of translating takes place in the socio-cultural context. Consequently, it is important to judge translating activity only within a social context.(Monireh Akbari-2013).

Translation, the act or process of rendering what is expressed in one language or set of symbols by means of anotherlanguage or set of symbols. It has for centuries been taken for granted that translation takes place between languages.Undoubtedly, as an important communication way, one of the basic principles of translation is to be faithful to theoriginal. According to this principle, translation should first be faithful to the content of original, with literal translationconveying the original cultural connotation in a precise way. Maybe cultural gaps are an obstacle when we dotranslation, but in my opinion, everything is translatable. Because translation is a "re-coding" or a change of surfacestructure in representation of the deep structure underlying it.(Jianqing Wu-2008). The Problem of StudyThe researcher discusses Difficulties and Problems that Face English Students of Al Quds Open University in Cultural Translation process from English to Arabic and Vice Versa and the solutions for the same. The study will answer the main question: What are the difficulties and 
problems that face English students of Al Quds Open University in cultural translation process from English to Arabic and vice versa and the solutions for the same?The following sub-questions arise from the main question:1- What is the difficulty level in choosing the suitable cultural translation style and terms from Arabic to English for English students at Al Quds Open University?2- What is the difficulty level in choosing the suitable cultural translation style and terms from English to Arabic for English students at Al Quds Open University?3What is the kind of strategy and method that used by the students at Al Quds Open University in cultural translation from English to Arabic ?4- What is the kind of strategy and method that used by the students at $\mathrm{Al}$ Quds Open University in cultural translation from Arabic to English ?5- Are there any statistical significant differences in the difficulties and problems that face English students of Al Quds Open University in cultural translation process from English to Arabic and vice versa refers to gender variable?The importance of the studyThe researcher noticed during his career and teaching the course of translation at Al Quds Open University that the students face difficulties and Problems in Cultural Translation process from English to Arabic and Vice Versa .The importance of such study lies in the following points:1-The research formulates a list of useful techniques and procedures for cultural translation to overcome such problems.2-The study will upgrade the level of cultural translation process from English language to Arabic language by adopting suitable techniques and procedures for accurate cultural translation.3-The research will draw the attention of the concerned parties to the importance of providing suitable procedures and requirements to improve cultural translation process from English language to Arabic language and vice versa.4-The study will draw the attention of persons in charge and the officials to the importance of student's role in achieving and carrying out effective for the purposes to create and produce accurate and perfect scientific translation. The Objective of the ResearchThe main objectives of the research of difficulties and problems that face the students of Al Quds Open University in cultural translation process from English to Arabic and vice versa and their solutions are:--Improving and developing students by using the skills, techniques and procedures of cultural translation that may enrich and assist the student's ability of cultural translation.-Adopting suitable cultural translation strategies for different kinds of scientific translation such as instructions, specifications, contents, terms ...etc.-To enable students to learn a range of linguistic and translation skills, including how to deal with the cultural dimension of translation, for the differences between the English and Arabic languages and to handle translated texts in specialized areas (e.g. cultural specifications, cultural reports, instructions ....etc.).

-To bring students to a level of practical proficiency that will enable them to be linguistically and analytically equipped to complete extended cultural translation assignments and deal with linguistically and culturallyrelated problems in cultural translation, increasing their confidence as practicing language professionals.Limitations of the StudyThe study has three limitations:-1-Limitation of timeThe study was carried out and applied in the first course of the academic year 2016/2017.2-Limitation of placeThe study was applied and carried out in Al Quds Open University in Gaza City Region.3-Subject Limitation

The study will deal with and discussthe Difficulties and Problems that Face English Students of Al Quds Open University in Cultural Translation process from English to Arabic and Vice Versa and the solutions for the same in Gaza City Region. Definition of TermsTranslation: It is an activity comprising the interpretation of the meaning of a text in one language - the source- and the other language the - target.Culture: The Arts and other manifestations of human intellectual achievement regarded collectively.Translation Difficulties: (individual) are difficulties that individual translators could have when dealing with the translation process.Translation Problems: (general) are linguistic phenomena known to be problematic in translation independent from the individual translator for example ambiguous words.Translation strategy: plans to solve problems that occur when reaching a particular translation goal.Ambiguity: The presence of two or more meanings in an utterance due to different possibilities of lexical, grammatical or pragmatic interpretation.Interpretation.:The action of explaining the meaning of some

Research methodology and procedureResearch methodologyThe researcher used "The analytical descriptive method" which is suitable for the nature and thevariable of the study in order to achieve its aims. Research populationThe research population consisted of the English students at Palestinian universities (Al-Quds open university- Al-Azhar university- Islamic university- Al Aqsa university) .Study sampleThe sample of study includes 44 English student were selected randomly from the study population. Research instrumentationThe researcher designed a test consists of fourquestions, the first one includes $15 \mathrm{item}$, the $2^{\text {nd }}$ one includes 15 item, the $3^{\text {rd }}$ one includes 5 items, and the $4^{\text {th }}$ one includes 5 items. The designed test aimed to measure the problems and difficulties that encounter English student at Palestinian universities in cultural translation as shown in table

(1).Table 1

\begin{tabular}{|c|l|l|}
\hline No & Question & $\begin{array}{l}\text { No of } \\
\text { items }\end{array}$ \\
\hline 1. & Translate the following terms in to English & 15 \\
\hline 2. & Translate the following terms in to Arabic & 15 \\
\hline
\end{tabular}




\begin{tabular}{|c|l|l|}
\hline 3. & Translate the following sentences in to English & 5 \\
\hline 4. & Translate the following sentences in to Arabic & 5 \\
\hline Total & 40 \\
\hline
\end{tabular}

Characteristics of the study toolInternal Validity

Internal consistencyThe researcher calculated the correlation Pearson coefficient between the scores of the study sample on each item and its main questions and main questions test total scores as shown in tables (2) ,(3), (4)\& (5)

Table (2) person correlation coefficient of question one items

\begin{tabular}{|l|l|l|l|l|l|}
\hline No & Correlation coefficients & $\begin{array}{l}\text { Sig } \\
\text { level }\end{array}$ & No & $\begin{array}{l}\text { Correlation } \\
\text { coefficients }\end{array}$ & Sig level \\
\hline 1. & 0.463 & 0.01 & 2. & 0.547 & 0.01 \\
\hline 3. & 0.432 & 0.01 & 4. & 0.512 & 0.01 \\
\hline 5. & 0.415 & 0.01 & 6. & 0.555 & 0.01 \\
\hline 7. & 0.708 & 0.01 & 8. & 0.779 & 0.01 \\
\hline 9. & 0.758 & 0.01 & 10. & 0.631 & 0.01 \\
\hline 11. & 0.802 & 0.01 & 12. & 0.759 & 0.01 \\
\hline 13. & 0.563 & 0.01 & 14. & 0.463 & 0.01 \\
\hline 15. & 0.713 & 0.01 & & & \\
\hline
\end{tabular}

** $\mathbf{R}$, critical value at degree of freedom 42 and sig level $0.01=0.393$

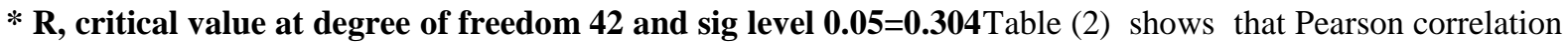
coefficient for each item with the total score of first question are significant at $\alpha \leq 0.01$ which confirms the internal consistency of first question. Table (3) person correlation coefficient of question two items

\begin{tabular}{|c|l|l|r|l|l|}
\hline No & $\begin{array}{l}\text { Correlation } \\
\text { coefficients }\end{array}$ & $\begin{array}{l}\text { Sig } \\
\text { level }\end{array}$ & No & $\begin{array}{l}\text { Correlation } \\
\text { coefficients }\end{array}$ & Sig level \\
\hline 1. & 0.523 & 0.01 & 2. & 0.553 & 0.01 \\
\hline 3. & 0.839 & 0.01 & 4. & 0.804 & 0.01 \\
\hline 5. & 0.767 & 0.01 & 6. & 0.861 & 0.01 \\
\hline 7. & 0.541 & 0.01 & 8. & 0.861 & 0.01 \\
\hline 9. & 0.764 & 0.01 & 10. & 0.578 & 0.01 \\
\hline 11. & 0.804 & 0.01 & 12. & 0.495 & 0.01 \\
\hline 13. & 0.530 & 0.01 & 14. & 0.709 & 0.01 \\
\hline 15. & 0.812 & 0.01 & & \\
\hline
\end{tabular}

** $\mathbf{R}$, critical value at degree of freedom 42 and sig level $0.01=0.393 * \mathbf{R}$, critical value at degree of freedom 42 and sig level $\mathbf{0 . 0 5}=\mathbf{0 . 3 0 4}$ Table (3) shows that Pearson correlation coefficient for each item with the total score of $2^{\text {nd }}$ question are significant at $\alpha \leq 0.01$ which confirms the internal consistency of $2^{\text {nd }}$ question.

Table (4) person correlation coefficient of question three items

\begin{tabular}{|c|l|l|r|l|l|}
\hline No & $\begin{array}{l}\text { Correlation } \\
\text { coefficients }\end{array}$ & Sig level & No & Correlation coefficients & Sig level \\
\hline 1. & $\mathbf{0 . 9 6 5}$ & $\mathbf{0 . 0 1}$ & 2. & $\mathbf{0 . 9 2 5}$ & $\mathbf{0 . 0 1}$ \\
\hline 3. & $\mathbf{0 . 7 7 9}$ & $\mathbf{0 . 0 1}$ & 4. & $\mathbf{0 . 8 4 3}$ & $\mathbf{0 . 0 1}$ \\
\hline 5. & $\mathbf{0 . 5 6 9}$ & $\mathbf{0 . 0 1}$ & & & \\
\hline
\end{tabular}

** $\mathbf{R}$, critical value at degree of freedom 42 and sig level $0.01=0.393 * \mathbf{R}$, critical value at degree of freedom 42 and sig level $\mathbf{0 . 0 5}=\mathbf{0 . 3 0 4 T a b l e ~ ( 4 ) ~ s h o w s ~ t h a t ~ P e a r s o n ~ c o r r e l a t i o n ~ c o e f f i c i e n t ~ f o r ~ e a c h ~ i t e m ~ w i t h ~}$ the total score of $3^{\text {rd }}$ question are significant at $\alpha \leq 0.01$ which confirms the internal consistency of $3^{\text {rd }}$ question.

Table (5) person correlation coefficient of question four items

\begin{tabular}{|l|l|l|l|l|l|}
\hline No & Correlation coefficients & Sig level & No & Correlation coefficients & Sig level \\
\hline 1. & $\mathbf{0 . 6 4 1}$ & $\mathbf{0 . 0 1}$ & 2. & $\mathbf{0 . 8 9 3}$ & $\mathbf{0 . 0 1}$ \\
\hline 3. & $\mathbf{0 . 8 2 5}$ & $\mathbf{0 . 0 1}$ & $\mathbf{4 .}$ & $\mathbf{0 . 7 1 0}$ & $\mathbf{0 . 0 1}$ \\
\hline 5. & $\mathbf{0 . 5 8 7}$ & $\mathbf{0 . 0 1}$ & & \\
\hline
\end{tabular}

$* * \mathbf{R}$, critical value at degree of freedom 42 and $\operatorname{sig}$ level $0.01=0.393 * \mathbf{R}$, critical value at degree of freedom 42 and sig level $\mathbf{0 . 0 5}=\mathbf{0 . 3 0 4}$ Table (5) shows that Pearson correlation coefficient for each item with the total score of $4^{\text {th }}$ question are significant at $\alpha \leq 0.01$ which confirms the internal consistency of $4^{\text {th }}$ question.Internal consistency of all test question Pearson correlation coefficient of each question with the total score of the testwas calculated in order to verify the internal consistency of the test question as shown in table (6) 
Table (6)person correlation coefficient of between each question and total score of translation test

\begin{tabular}{|l|l|l|l|l|}
\hline No & Q 1 & Q2 & Q3 & Q4 \\
\hline Q1 & - & - & - & - \\
\hline Q2 & $\mathbf{0 . 7 3 8 * *}$ & - & - & - \\
\hline Q3 & $\mathbf{0 . 8 1 5 * *}$ & $\mathbf{0 . 5 4 7 * *}$ & - & - \\
\hline Q4 & $\mathbf{0 . 7 9 5 * *}$ & $\mathbf{0 . 6 2 4} * *$ & $\mathbf{0 . 7 6 2} * *$ & \\
\hline Total score & $\mathbf{0 . 9 5 4}$ & $\mathbf{0 . 7 8 8} * *$ & $\mathbf{0 . 8 7 9} * *$ & $\mathbf{0 . 9 0 7 * *}$ \\
\hline
\end{tabular}

** $\mathbf{R}$, critical value at degree of freedom 42 and sig level $0.01=0.393 * \mathbf{R}$, critical value at degree of freedom 42 and sig level $\mathbf{0 . 0 5}=\mathbf{0 . 3 0 4 T a b l e ~ ( 6 ) ~ s h o w e d ~ t h a t ~ p e r s o n ~ c o r r e l a t i o n ~ c o e f f i c i e n t ~ b e t w e e n ~ e a c h ~}$ question and the total score of translation test are statistical significant at $\alpha \leq 0.01$ level which confirmed the internal consistency and validity of questionnaire to apply on the sample of the research.ReliabilityThe researcher used alpha Cronbach's equation in order to determine the reliability of researcher's instrument as shown in table (7)

Table (7) alpha Cronbach's coefficient

\begin{tabular}{|l|l|l|l|}
\hline No & Domain & Number of item & alpha Cronbach's coefficient \\
\hline Q1 & Translate the following terms in to English & 15 & 0.854 \\
\hline Q2 & Translate the following terms in to Arabic & 15 & 0.924 \\
\hline Q3 & Translate the following sentences in to English & 5 & 0.880 \\
\hline Q4 & Translate the following sentences in to Arabic & 5 & 0.782 \\
\hline \multicolumn{2}{|l|}{ Total score } & 40 & 0.936 \\
\hline
\end{tabular}

Table (7) shows that Cronbach's alpha coefficient for each question and total degree of test are high coefficient which indicated that the test is reliable to apply on the sample of the research.Statistical MethodsThe researcher analyzed the data by (statistical package for social science program SPSS) using the following statistical methods: -

1-Means, standard deviation, relative weight. 2-Person correlation formula.3-Cronbach's alpha to measure the tool of study reliability .

Agreement of refereesThetest was introduced for a group of specialized linguistics university tutors and lecturers at Gaza Governorate. They provided their recommendations and suggestions about the validity of the items of the exam. The researcher amended and modified such test upon the suggestions and recommendations of the referees.

\section{Previous Studies}

Ioana Irina Durdureanu 2011This paper aims at answering the very question of the possibility or impossibilityof thetranslation of culture, by presenting some of the most popular theories related to theculturebound terms and their equivalents. Translation and culture are so interrelated thattranslators can no longer ignore cultural elements in a text. That is why, before analyzing some translation theories related to cultural studies, it is very important to establish whatculture is and what the problems raised by its passage into a different community are. Everylanguage has its own way to perceive reality, which influences the way in which reality isexpressed by the members of a community. When translating, people find out things aboutothers, about a world which is not theirs. If translation did not exist, it would be difficult tocommunicate with people from other countries, by communication meaning not only thetransmission of words and phrases but also the sense of a text, because what translatorsshould translate is messages, senses, and texts. Different translation scholars offer variousways in which translation problems could be solved so that the receiving audience mayperceive the culture and the otherness of another world. Finally, to a certain degree andlosing a part of the otherness of the source culture, culture can be translated by using sometranslation methods like the so-called equivalence, according to the functionalist theories.Roxana Mareş 2012Translation is an activity of enormous importance in the modern world and has become an established area in language studies, being the main criterion for achieving communication.Considering Newmark's theory that translation is an art as well as a skill and a science, three main aspects are taken into consideration when we talk about translation: the foreign and native cultures, the two languages and the writer and the translator.In the case of Arabic, translations are viewed from a different perspective. The knowledge of the Arabic culture is crucial for English - Arabic translation.Inaccurate translations reveal the mismatches in beliefs and cultural norms between the Western cultures and the Arab culture. The influence of culture on language heritage is manifested between identity and culture. Secondly theduality of Arabic is another important aspect related to translations differences.It is useful for 
English - Arabic translators to be aware that differences between the two linguistic systems may cause problems in translation, for this reason the author tries to specithe most frequent linguistic errors in English Arabic translations.

\section{Monireh Akbari 2013}

This paper first illustrates the crucial interplay between culture and language and then emphasizes the role of culture in translation. Within the scholars in the field of translation studies a myriad number of individuals have theorized about the role of culture in translation and each of them has his /her own viewpoint, this study has tried to review them briefly and at the end some strategies for the translation of culture-specific items have been proposed.

\section{Jianqing Wu 2008}

This paper is about cultural gaps and their translation. It compares the different cultural connotations of expressions inEnglish and Chinese. First, it analyzes the following cases which are often found in translation: cultural background;non-equivalence; extension and intension;derivation. Then six methods are put forward to solve those above problems.

\section{Amin Ali Almubark, Dr.AmerrudinAbd. Manan,Associate Professor KhairiObaidTayyeh Al-Zubaid 21014}

This paper investigates problems faced by undergraduate students in Sudan majoring in English language when translating specific cultural concepts from Arabic language into English language. To attain this aim, the researcher randomlyselected 100 undergraduate students who were registered for the B.A program inthe Department of English at Al Imam AlMahdi University in Sudan during the 2012/2013 academic year. The researchers carried out a translation test that consisted of 18 sentences which the learners were then required to translate from Arabic into English. Each sentence comprised of specific cultural concepts based on Newmark's (1988) classification of cultural terms. The researchers also carried out interviews with lecturers who specialize in translation to get further data from their point of view concerning these difficulties, the reasons and their proposed solution. The findings show that the undergraduate learners faced various types of complications when translating specific cultural concepts. These difficulties are frequently associated with; 1) translating specific cultural concepts, 2) unsuccessful attempts to attain the sameness in English language, and 3) lack of knowledge of translation techniques and translation strategies. Based on this result, this research work proposes a solution to narrow the gap between specific cultural concepts such as figuring out programs that deals with specificcultural conceptsthat suit translators.

\section{Ali Sulaimaan I. Addulaimi 2012}

One of the most important approaches to translation is the socio-semiotic or cultural approach which means that translation is not restricted to the meanings of sounds, words, grammar and rhetoric but it goes beyond mere correspondences to cultural presuppositions and value systems which create a different world picture specific to every culture (Nida, 1985:121). This paper aims at pointing different problematic areas in translation that result from differences in culture to which the two languages belong.

\section{Mahmoud Ordudari 2007}

Translating culture-specific concepts (CSCs) in general and allusions in particular seem to be one of the most challenging tasks to be performed by a translator; in other words, allusions are potential problems of the translation process due to the fact that allusions have particular connotations and implications in the source language (SL) and the foreign culture (FC) but not necessarily in the TL and the domestic culture. There are some procedures and strategies for rendering CSCs and allusions respectively. The present paper aims at scrutinizing whether there exists any point of similarity between these procedures and strategies and to identify which of these procedures and strategies seem to be more effective than the others.

\section{RadegundisStolze 2009}

Culture is the background of every human communication. Cultural embedding as afeature of texts in general is also valid in technical and scientific texts. As translation byhumans is based on understanding, the translator needs knowledge in order to detectcultural aspects. This is possible by putting down implicit cultural references to certainstructures on the text level. Cultural elements appear in the text on all levels - from theconcept and form of words, to the sentence and text structure, to pragmatics. Examplesfor the various appearances are presented in the first part of the paper.The second part discusses translation as a writing process. Here the categories ofattention governing the translator's approach are presented. Taking a holistic view of thetext, the translator may consider the relevant cultural context, discourse field, conceptualworld and 
predicative mode to promote his or her understanding. The target languageformulation will then observe the medium, stylistics, coherence and function of the text.Dealing with cultural elements may be motivated in view of the aforementionedcategories of attention.

\section{MaisaaTanjour 2011}

Literary translation is the result of the interaction of culture, ideology and translation. It isalso considered to be one of the most interesting challenges within a specific literary systemdue to its special nature and the variation in the cultural environment between source andtarget. Researching such challenges entails investigating the different factors that governthe translation process and product alongside its reception by a specific readership.This thesis is located within the framework of translation studies suggested by Holmes(1988) and developed by Toury (1995), as partly descriptive and partly process-receptionoriented. It employs empirical interviews to investigate and describe the differenteconomic, political, cultural and ideological factors that govern the translation process andproduct in Syria. Such a description provides the background for the assessment of theresponses of groups of target readers to a specific text.In this research, D. H. Lawrence's The Virgin and the Gipsyand two Arabic translationsare used as a sample analysis of the translation procedures adopted to tackle culturespecificreferences. The manual analysis in Chapter 5 of the cultural references in TheVirgin and the Gipsy leads to the conclusion that translation procedures adopted in thepublished translations are unsystematic and that the two translators may not be fully awareof the effects of the chosen procedures on their target readers.The empirical methods are twofold. Interviews were carried out with Syrian publishersto explore the Syrian publishing conditions. The results yield a description of the socioculturalcontext of translation in Syria. Within that context, the responses of particulargroups of target readers (English Literature graduates) to certain translation procedures areexamined and then used to investigate the acceptability of the procedures used mainlyendnotes and interpolations based on the students' responses to them. Four questionnaireswere conducted with forty Syrian students. The results show that endnotes andinterpolations are acceptable translation procedures in translating certain culture-specificreferences, depending on the needs of target readers and the importance of the culturalreference in understanding the text.This research demonstrates the potential of using reader-response theory and methods inanalyzing translation procedures that are adopted to deal with culture-specific references.The results suggest that extensions and modifications of empirical models are necessary togauge target readers' responses and to show how such enquiries can be used in translationstudies.

\section{The Comment on Previous Studies}

In comparison with the studies carried out on difficulties and problems that encounter English Students of Al Quds Open University in Cultural Translation process from English to Arabic and vice versa and the solutions for the same, these studies deal only with one topic and one kind.The paper ofIoana Irina Durdureanuaims at answering the very question of the possibility or impossibility of thetranslation of culture, by presenting some of the most popular theories related to theculture-bound terms and their equivalents. Translation and culture are so interrelated thattranslators can no longer ignore cultural elements in a text. Roxana Mareşfocuses onthree main aspects to be taken into consideration when we talk about translation: the foreign and native cultures, the two languages and the writer and the translator.Monireh Akbari'spaper illustrates the crucial interplay between culture and language and then emphasizes the role of culture in translation. The paper of Jianqing Wu is about cultural gaps and their translation. It compares the different cultural connotations of expressions inEnglish and Chinese.The paper of Amin Ali Almubark, Dr.AmerrudinAbd. Manan,Associate Professor KhairiObaidTayyeh Al-Zubaid investigates problems faced by undergraduate students in Sudan majoring in English language when translating specific cultural concepts from Arabic language into English language. Regarding the paper of Ali Sulaimaan I. Addulaimi aims at pointing different problematic areas in translation that result from differences in culture to which the two languages belong.Mahmoud Ordudari believes thatthere are some procedures and strategies for rendering CSCs and allusions respectively. His paper aims at scrutinizing whether there exists any point of similarity between these procedures and strategies and to identify which of these procedures and strategies seem to be more effective than the others.RadegundisStolzebelieves that cultural elements appear in the text on all levels - from theconcept and form of words, to the sentence and text structure, to pragmatics.Examplesfor the various appearances are presented in the first part of the paper.The second part discusses translation as a writing process.MaisaaTanjour'sresearch demonstrates the potential of using reader-response theory and methods inanalyzing translation procedures that are adopted to deal with culture-specific referencesThis study deals with difficulties and problems that face the students of Al Quds Open University in cultural translation process from English to Arabic and vice versa and their solutions. 


\section{Literature Review}

\subsection{Defining translations}

Catford $(1965,1)$ defines translation as "a process of substituting a text in one language for a text in another". Thus, translation is considered an operation performed on languages. Catford builds his definition on the concept of equivalence, describing translation as the replacement of textual material in one language by equivalent textual material in another language. He considers the central problem of translation to be finding target language equivalents. Catford distinguishes between full and partial translation, depending on the extent to which the source language text is submitted to the translation

process. According to him, translating consists, in reproducing RL (receptor language) closest natural equivalent of the SL (source language) message, first in terms of meaning and secondly in terms of style. According to him, the basis to any discussion of principles and procedures in translation is a thorough acquaintance in the manner in which meaning is expressed through language as communication code. He gives importance to the communicative aspects of translation. His views on translation are essentially discourse oriented with a focus on the various socio-linguistic variables, which determine the nature

of the translation. He propounds a pragmatic theory of translation by considering the connotative or pragrammatic as the central focus in transforming the message from the source language to the receptor language.He says, "basic to any discussion of principles and procedures in translation is a through acquaintance in the manner in which meaning is expressed through language as a communication code - first in terms of parts which constitute such a code; secondly, the

manner in which the code operates; and thirdly, how such code as language is related to other codes. Nida in his theory of translation gives importance to the communicative aspect of translation. His view of translation is essentially discourse oriented with focus on the various socio-linguistic variables, which determine the nature of the translating. The role of the receptor is central to his theory of translation.(Nida and Taber 1969, 31). Nida and Taber emphasize the importance of understanding the original text before constructing the target language text. Nida $(1964,14)$ argues that "Translation is the

interpretation of verbal signs of one language by means of verbal signs of another".Newmark $(1981,7)$ defines translation as "a craft consisting in the attempt to replace a written message and/or a statement in one language by the same message and/or statement in another language". He $(1988,5)$ states that "translation is rendering the meaning of a text into another language in the way that the author intended the text". Newmark (1981,18) shares Benjamin's (1932) view that translation goes beyond enriching the language and culture of a country which it contributes to, beyond renewing andmaturing the life of the original text, beyond expressing and analysing the most intimate relationships of languages with each other and becomes a way of entry into a universal language.As a functionalist, Halliday defines the goal of a functional theory of language as explaining linguistic structure, and linguistic phenomena, by reference to the notion that language plays a certain part in our lives; that it is required to serve certain universal types of demand. It pproaches language through text. His theory establishes six levels:-Social system: the world of abstract relations and consciousness as well as the physical world.-Register: the variety of language used in a particular situational context or the contextual dimensions of social meaning. This represents the sociocontextual or semiotic resources from a socio-cultural system, which apply in a given situation, determining the choice of meaning options in the semantic system of language.-Semantics: register is realized by semantics. It has three functional components:ideational, interpersonal and textual (Morley 1985, 50-81).Lexicogrammar: this realises the semantics. It is the level of wording (Morley 1985, 49).-Phonology: this realizes lexicogran-unar. It is the level of sounding (Morley 1985, 49).-Phonetics: this is the ultimate 'output', and involves the actual sounds, which are uttered, or the physical graphic marks in writing (Morley 1985, 49).

\section{Defining culture and culture-bound terms}

Translation is seen nowadays as an important human action and the translator as amediator between cultures. That is why many scholars have asked how or if culturecan be eventually translated into another language. Translation is always placed atthe core of the intercultural aspects, so that the study of the translation goes alongwith the cultural studies. Consequently, cultural aspects of translation haveemerged into a series of theories about cultural translation, about its very existencein terms of cultural identity of a specific community. From the beginning, we mayask what culture is. This is not an easy question to answer. In Duranti's opinion,culture is "something learned, transmitted, passed down from one generation to thenext, through human actions, often in the form of face-to-face interaction, and, ofcourse, through linguistic communication" (Duranti 1997:24, cited in Thanasoulas2001). From this definition, we can observe that language plays a very importantrole in a culture. Pierre Bourdieu has emphasized the importance of language as asystem determined by socio-political processes. In his opinion, language exists asa linguistic habitus (1990:52), which implies not only a particular system of wordsand grammatical rules, but also a symbolic power of a particular way 
ofcommunication, with specific patters for every community (particular systems ofclassifications, specialized lexicons, metaphors, reference forms, etc.). To speakmeans to choose a particular way of viewing the world, a particular way ofestablishing contacts. According to Bourdieu, in a wider sense, we are members ofa community of ideas and practices through the language we speak. Therefore, language is linked to culture, as a link between thought and behaviour. Durantiobserves thatwords carry in them a myriad possibilities for connecting us to other humanbeings, other situations, events, acts, beliefs, feelings... The indexicality oflanguage is thus part of the constitution of any act of speaking as an act ofparticipation in a community of language users. (Duranti 1997:46)According to Goodenough (1981:62, cited in Thanasoulas 2001), culture is: The ways in which people have organized their experience of the realworld so as to give it structure as a phenomenal world of forms, their precepts andconcepts. The ways in which people have organized their experience of theirphenomenal world so as to give it structure as a system of cause and effectrelationships, that is, the propositions and beliefs by which they explain events andaccomplish their purposes.

- The ways in which people have organized their experiences so as tostructure their world in hierarchies of preferences, namely, their value or sentimentsystems. The ways in which people have organized their experience of their pastfforts to accomplish recurring purposes into operational procedures foraccomplishing these purposes in the future, that is, a set of "grammatical"principles of action and a series of recipes for accomplishing particular ends.Moreover, for Goodenough (1963:258-259, cited in Thanasoulas 2001)culture "consists of standards for deciding what is, standards for deciding what canbe, standards for deciding how one feels about it, standards for deciding what to doabout it, and standards for deciding how to go about it". Another translationscholar, Peter Newmark, defines culture as "the way of life and its manifestationsthat are peculiar to a community that uses a particular language as its means ofexpression" (1988:94). Consequently, each community has its own particularcultural patterns. The translator's role becomes clearly a transcultural mediatorbetween communities. Newmark sustains (1988:95) that language is not a

component of culture, whereas Hans Vermeer remarks (2000:222) that language ispart of a culture. In these terms, Newmark says that, in Vermeer's opinion, it wouldbe impossible to translate cultural elements.

\section{The Concept of Culture:}

The anthropologist Malinowiski (1962:169) defines culture as "the fullest context of all human activities. It is the vast instrumentality through which man achieves his ends both as an animal that must eat, rest, and produce; and the spiritual being who desire to extend his mental horizons, produce works of art and develop systems of faith"Haviland (1975:12) defines culture as "a set of rules and standards which when acted upon by the members of a society produce behaviour that falls within a range of variance that readers consider proper or acceptable"(for further details, see Muhammad 1986).The fabric of society operates and becomes visible through our use of language. This fabric includes the social context of language use which naturally presupposes the existence of a particular society. Society has implicit and explicit values, norms and laws, and with all its particular conditions of life: economic, social, political and cultural (cf Davis 1977: 21- 57).Culture is defined as the way of life and its manifestations, which are unique to a society that uses a particular language as a means of expression (Newmark, 1988:94).Culture may be defined as a set of beliefs, which governs the behaviour patterns of a society. These beliefs include religion, economy, politics, literature and language. Thus, language is an integral part of culture, and translation involves two cultures, the culture of the source language(source culture) and the culture of the target language(target culture)(Aziz and Muftah, 2000:85).

\section{Cultural Differences between Western Culture and the Arab World}

Culture is the complex whole, which includes knowledge, belief, art, morals, law, customs, and any other capabilities or habits acquired by man as a member of society (Taylor 1958,1). It is the set of general meanings that people use to explain their origins,and to predict their future. Culture plays an essential role in determining the appropriateness of linguistic units. In addition, cultural variables affect the degree of understanding between two language communities (cf. Kussmaul 1995, 65). As a result, language is an integral part of culture because the vocabulary of a language derives its meaning from its culture. Arabic is associated with specific cultural and social norms quite different from those, associated with other languages. According to Sapir (1949), "environment and culture have a considerable influence on the language of speakers as is clearly seen in their vocabulary". Through translation, translators become transmitters ofdifferent civilizations. Inevitably to some extent, any translation will reflect the translator's own mental and cultural outlook, despite the best of impartial intentions. Every translator has her/his own beliefs, knowledge and attitudes. "A target language culture can also be extended by the introduction of new ideas and styles... the translational act may give rise to new forms of the target language" (Holman and Boase-Beier 1999, 15). Discrepancy in cultural beliefs, norms and linguistic expression between the two cultures and languages is responsible for difficulties in English/ Arabic translation. Cultural differences often impose greater difficulty for translators than linguistic features such as language structure. 
There are often cultural gaps caused by different aspects of societies, which lead to linguistic gaps. Therefore, finding translation equivalents for cultural terms requires the bridging of the cultural and linguistic gaps and meeting readers' expectations. "Translators have to be aware of the fact that readers' expectations, their norms and values, are influenced by culture and that their comprehensions of utterances is to a large extent determined by these expectations, norms and values" (Kussmaul 1995, 70).

A lot of the translation difficulties discussed in this chapter are closely connected to the distinction in Arabic between Standard Arabic and colloquial Arabic r+4. .1-.3) (Dickins et al 2002, 167).

Translation from English to Arabic is normally bound to be into Standard Arabic rather than colloquial Arabic. Although Arabic has colloquial equivalents for many English terms, Standard Arabic has limited terms. Standard Arabic is also intrinsically formal in register terms. So, there are almost no informal terms available in Arabic to relay informal English ones. Some of the translation problems presented in this chapter involve the interaction between cultural and linguistic problems. They often involve the lack of equivalents in Standard Arabic for certain English terms. It is the role of the translator to

understand the applications and connotations of words and determine suitable equivalents in specific contexts. The translator should decide whether to use the original term to preserve the essence of meaning of the culture-bound word or to use an appropriate translation equivalent. Borrowings can often be used to fill lexical gaps but they sometimes need an explanatory gloss. Sometimes, a translation equivalent shows links between languages and can bridge the lexical gap between the source and target language.General cultural background about the first three cultural aspects is provided. This

general background illustrates a number of differences between Western, and particularly British, and Arabic cultures, which are expected to be problematic in English/Arabic translation. Some examples of translation difficulties from the research translation sampleare also provided. Due to limitations of time and space, these texts are limited to political, social and religious aspects of culture. In fact, translation difficulties appeared in virtually all of the translated texts. These difficulties illustrate that cultural texts can pose difficulties for some students of a degree that hinders target readers' understanding. Better

understanding of Western culture is important for translators to overcome cultural difficulties in English/Arabic translation..( RoxanaMareş 2012)

\section{Translation and Culture:}

It is a commonplace fact that cultural presuppositions and value system create, by virtue of cultural specificity, a mental set characteristic of each culture and it is expected that various mental sets overlap between one language and another, but they rarely match exactly. These mental sets as reflected by language look like some invisible borderlines drawn across the world image, which does not largely differ among and between languages.For instance, in the western world, dragons are regarded as symbols of dire danger and as such they fit in the Book of Revelation which harbours several terrible creatures besides the dragons while the dragon is normally regarded as a symbol of good luck in the Orient.Several events recorded in a text may likewise have quite different meanings because of different cultural values. For instance, among the Muslims the story of Ibrahim and Ishmael is regarded as one of the most significant proofs of the grace of God while less significance is attached to this story in the western world. Also kings of Israel are considered prophets in the GloriuosQur'a:n and Solomon in particular is almost mythified while in the Old Testament they are all represented as historical figures. This impression of the Muslims, therefore, differs from that of the western man of those figures since each culture is influenced by a different prototype. A sociosemiotic approach to translation has led to some problems of meaning and ambiguities since the cognitive structure or rather the mapping of the cognitive structure as reflected in words does not match among cultures. Among these problems are the distinction between the designative and the associativemeanings (which paralleled to some extent, the distinction between denotation and connotation) and the metaphoric representation (Nida, 1985:21-3).

The above mentioned aspect becomes clear in the representation of colours in different cultures. The word (black) for instance, is a term of abuse or insult in several white cultures while the designative meaning of the same word in a white culture does not contain or suggest any pejorative shock. The term of insult is another example, "you cow" does not mean anything pejorative in an Indian culture nor does "a mouse" in China mean any passive connotation. On the other hand, designatively both "cows" and "mice" can be used neutrally in all cultures(Dulf, 1984:11-2).

Related to this problem is that of cultural relativity of peacocks, pandas, camels kangaroos, and penguins are representatives of India China, Arabia, Australia and Eskimos equally as representatives of their respective species. Snow regions as contrasted to desert regions have created different metaphors relating snow in the former and heart in the latter to boon and pleasant things. Different parts of the body are given different weights of significance in different cultures thus affecting not only the aesthetic standards but the metaphors attached to these standards. 
Also, it is often broadly admitted that since language is an embodiment of an underlying human common experience which the thesis of linguistic universals implies the translator's job is to actualize this presupposition whatever the peculiarities of the language he is dealing with.A narrow consideration of the concerned languages, however, shows that the above assumption is not quite adequate because it aims at universalization of usage while ignoring at the same time cultural variations.

Ecology, it is my impression, does not homogenize but it rather determines linguistic variance across cultures. First let's assume that an Arab native speaker receives good news and that he must formulate his psychological enjoyment into a sentence. He will literary say:"This news freezes my chest"A statement which, to say the least, will seem particularly bizarre to his English interlocutor. The reason for this unusual wording of the experience of the Arab can only be explained with reference to the ecological conditions of the Arabian Desert which structure and explain his repertoire of metaphoric images.Needless to say, that the translator handles such a culturally- bound expression with the idea of giving it back into English. He certainly does not need to be weather specialist to find the appropriate corresponding expression. The Arab item is cold oriented whereas the English item is hot- oriented, each of them responding respectively to his environment conditions. Moreover, this item shows a difference in terms of the symbolic representation of affectivity which is represented by the physical organ "chest" for the Arab and by "the heart" for the English.Culture- bound expressions explicitly spot light the cultural relativity and prove that the Linguistic Universal Theory does not comprehensively hold in time and place.Let's take some local examples, Satan the crow, the Magi and the Jew. Different cultures harbour different systems of beliefs what is held sacred for an Indian can only be viewed with horror or disrespect for an Arab. Satan is worshipped by the Yezidiz while damned by Muslims. In reviewing the folklore of the Middle East nations two phenomena stand out. The first is the hostility between the Arabs and Persians; the second is hatred between Jews and Muslims. The first discord isnational and racial while the second one is principally religious and historio-political.

For many Muslims, the term "Jew" is a term of insult. It is a synonym of niggardly, miser, mean and lousy, while the term "magus" stands for passive association. Whether derived from the Arabian Nights or some other sources, this sterio-typical example betrays cultured bias and as such cultural relativism. A cow to a North African is an animal of boon on good omen while an owl is a bird of bad omen to most nations. It is not the bird by any characteristic ominous but rather human bias which associates this bird to deserted and directed places. Being a night bird....the associative meaning thus single out certain entities as being positives or passively. When these entities, say animals, and colours, are used in a text like Chinese, Indian, Russian, Arab or English they definitely cannot show their positivism or passivism. "Black" certainly is a benign colour for African Negroes thus affecting not only language but the aesthetic sense (cf Nida, 1985:123).

\section{Types of Cultural Problems of Translation:}

Aziz and Muftah( 2000:90) say that cross-cultural translation may constitute many problematic areas. This is true of translation between English, which represents part of the western culture, and Arabic, which belongs to the oriental culture.

\section{1- Geographical Culture:}

Two cultures involved in translation may have divergent backgrounds related to such topics like animals, plants and climate. The Arabic speaking person may be said to inhabit States generally characterized by a hot and dry climate like Iraq, Syria, North Africa etc, whereas the culture of Western Europe is cold and wet. Within these two cultural frameworks, the different geographical terms will acquire different shades of meaning for the people using them.

\section{2- Religious Culture:}

Religion has deep roots in many different cultures and is revealed in how people speak and behave. However, some communities are more religion conscious than others. In general, the impact of religion is stronger and more obvious in the East than it is the West.

\section{3- Social Culture:}

Social ideologies raise a number of problems. These include the attitudes of various societies toward love, marriage and the concept of decency.

\section{4- Material Love}

The term material love has a broad sense and includes such things as food, means of transport and other objects that people use in their daily life. These may be different from one community to another. Developed Countries would deal with various material things like E-mail and WWW, which may not be found in Developing Countries. 


\section{5- Linguistic Culture:}

How people view the external world and what distinctions they draw between its various parts are likely reflected in their language: some linguists draw a distinction among three basic language functions. These functions are ideational, interpersonal and textual. They are realized differently in different languages. At the ideational function, for example, English recognizes two terms as far as the number system is concerned: the singular which means( one) and the plural which means(more than one) whereas Arabic distinguishes three terms: singular which means( one), dual which means( two) and plural which means(more than two).

\section{Religious facts}

Islamic beliefs are connected with every aspect of Muslim social culture even proper names. "Mohammed" and "Abdullah" are common names in Islamic culture because they have religious significance. Many of the Muslims choose their children's names from the Quran, names of prophets, compound variations of -14a "slave", "servant" and the names

of "God" or religious occasions. Parents believe that these names will bless their children.

So, Arab societies are more conventional and traditional in using proper names than Western societies. It is difficult for the target language reader to understand the religious dimensions related to such proper names. Traditional proper names may also be a good indicator of social and cultural background. For instance, urban communities have a greater tendency to use new names than rural communities. Sometimes, it may be appropriate to have a footnote in the translation to explain the related social and cultural aspects or religious dimensions of proper nouns.Islamic-based greetings are another important aspect of Muslims' daily life.Expressions of good will, resignation to God, self-ingratiation and other forms of social grace have different social functions.( Roxana Mareş 2012)Analyzing the Research Results and Answering the

\section{Questions}

The result of the main question "what are the most problems and difficulties that encounterthe English student at Palestinian universities in cultural translation?Means,standard deviations, relative weight, difficulties level and rank were computed for each question of translation test and its total score as shown in table (8)

Table (8) mean, standard deviation, relative weight, difficulties level, rank for each domain of test and its total score

\begin{tabular}{|l|l|l|l|l|l|l|}
\hline No & Translation type & Mean & SD deviation & $\begin{array}{l}\text { Relative } \\
\text { weight }\end{array}$ & Difficulties level & Rank \\
\hline $\mathbf{1 .}$ & $\begin{array}{l}\text { Translation terms from Arabic in to } \\
\text { English }\end{array}$ & 9.14 & 4.06 & 60.91 & 39.09 & 4 \\
\hline $\mathbf{2 .}$ & $\begin{array}{l}\text { Translation terms from English in to } \\
\text { Arabic }\end{array}$ & 8.73 & 5.09 & 58.182 & 41.82 & 3 \\
\hline $\mathbf{3 .}$ & $\begin{array}{l}\text { Translation sentences from Arabic in } \\
\text { to English }\end{array}$ & 5.91 & 5.87 & 39.39 & 60.61 & 1 \\
\hline $\mathbf{4 .}$ & $\begin{array}{l}\text { Translation sentences from English in } \\
\text { to Arabic }\end{array}$ & 8.09 & 5.33 & 53.94 & 46.06 & 2 \\
\hline Total & 31.86 & 17.87 & 53.11 & 46.89 & \\
\hline
\end{tabular}

Table (8) shows that translation sentences from Arabic into English had the first difficulties rank (60.61), translation sentences from English into Arabic had $2^{\text {nd }}$ rank (46.06), translation terms from English into Arabic had $3^{\text {rd }}$ rank, Translation terms from Arabic into English had the last rank (39.09), and the total score of difficulties level was (46.06) which means that the level of problems and difficulties that encounter the English student at Palestinian universities in cultural translation is high and the highest problems and difficulties that encounterthe English student at Palestinian universities in cultural translation is translation sentences from Arabic into English, and the lowest is Translation terms from Arabic into English.-Results of question one "what is the level of problems and difficulties that encounter the English students at Palestinian universities in culture terms translation from Arabic in to English?Means, standard deviations, relative weight, difficulties level and rank were computed of each item of question and its total score as shown in table (9)

Table (9) Means, standard deviation, relative weight, cultural terms translation difficulties level

\begin{tabular}{|l|l|l|l|l|l|}
\hline No & Mean & $\begin{array}{l}\text { SD } \\
\text { deviation }\end{array}$ & $\begin{array}{l}\text { Relative } \\
\text { weight }\end{array}$ & $\begin{array}{l}\text { Difficulties } \\
\text { level }\end{array}$ & Rank \\
\hline 1. & 0.82 & 0.39 & 82 & 18 & 14 \\
\hline
\end{tabular}




\begin{tabular}{|l|l|l|l|l|l|}
\hline No & Mean & $\begin{array}{l}\text { SD } \\
\text { deviation }\end{array}$ & $\begin{array}{l}\text { Relative } \\
\text { weight }\end{array}$ & $\begin{array}{l}\text { Difficulties } \\
\text { level }\end{array}$ & Rank \\
\hline $\mathbf{2 .}$ & 0.82 & 0.50 & 82 & 18 & 14 \\
\hline $\mathbf{3 .}$ & 0.41 & 0.50 & 41 & 59 & 2 \\
\hline $\mathbf{4 .}$ & 0.59 & 0.50 & 59 & 41 & 7 \\
\hline $\mathbf{5 .}$ & 0.68 & 0.47 & 68 & 32 & 11 \\
\hline $\mathbf{6 .}$ & 0.64 & 0.49 & 64 & 36 & 8 \\
\hline $\mathbf{7 .}$ & 0.50 & 0.51 & 50 & 50 & 3 \\
\hline $\mathbf{8 .}$ & 0.73 & 0.45 & 73 & 27 & 12 \\
\hline $\mathbf{9 .}$ & 0.64 & 0.49 & 64 & 36 & 8 \\
\hline $\mathbf{1 0 .}$ & 0.73 & 0.45 & 73 & 27 & 12 \\
\hline $\mathbf{1 1}$ & 0.64 & 0.49 & 64 & 36 & 8 \\
\hline $\mathbf{1 2 .}$ & 0.50 & 0.51 & 50 & 50 & 3 \\
\hline $\mathbf{1 3 .}$ & 0.36 & 0.49 & 36 & 64 & 5 \\
\hline $\mathbf{1 4 .}$ & 0.55 & 0.50 & 55 & 45 & 5 \\
\hline $\mathbf{1 5 .}$ & 0.55 & 0.50 & 55 & 45 & \\
\hline Total & 9.14 & 4.06 & 60.91 & 39.09 & \\
\hline & & & & & \\
\hline
\end{tabular}

The above table showed that item (13) and (3) were the highest difficulties level and item (1) (2) were the lowest and the total score difficulties level was (39.09) which mean that the level of problems and difficulties that encounter the English students at Palestinian universities in culture terms translation from Arabic in to English is high.-Result of question two "what is the level of problems and difficulties that encounter the English students at Palestinian universities in culture terms translation from English into Arabic? Means, standard deviations,relative weight, difficulties level and rank were computed of each item of $2^{\text {nd }}$ question and its total score in order specify the difficulties of terms translation from English to Arabic as shown in table (10)

Table (10) Means, standard deviation, relative weight, cultural terms translation difficulties level from English in to Arabic

\begin{tabular}{|l|l|l|l|l|l|}
\hline No & Mean & $\begin{array}{l}\text { SD } \\
\text { deviation }\end{array}$ & $\begin{array}{l}\text { Relative } \\
\text { weight }\end{array}$ & $\begin{array}{l}\text { Difficulties } \\
\text { level }\end{array}$ & Rank \\
\hline 1. & 0.64 & 0.49 & 63.64 & 36.36 & 9 \\
\hline 2. & 0.77 & 0.42 & 77.27 & 22.73 & 15 \\
\hline 3. & 0.73 & 0.45 & 72.73 & 27.27 & 14 \\
\hline 4. & 0.55 & 0.50 & 54.55 & 45.45 & 4 \\
\hline 5. & 0.64 & 0.49 & 63.64 & 36.36 & 9 \\
\hline 6. & 0.64 & 0.49 & 63.64 & 36.36 & 9 \\
\hline .. & 0.64 & 0.49 & 63.64 & 36.36 & 9 \\
\hline 8. & 0.64 & 0.49 & 63.64 & 36.36 & 9 \\
\hline 9. & 0.59 & 0.50 & 59.09 & 40.91 & 7 \\
\hline 10. & 0.41 & 0.50 & 40.91 & 59.09 & 2 \\
\hline 11. & 0.55 & 0.50 & 54.55 & 45.45 & 4 \\
\hline 12. & 0.55 & 0.50 & 54.55 & 45.45 & 4 \\
\hline 13. & 0.36 & 0.49 & 36.36 & 63.64 & 1 \\
\hline 14. & 0.59 & 0.50 & 59.09 & 40.91 & 7 \\
\hline 15. & 0.45 & 0.50 & 45.45 & 54.55 & 3 \\
\hline Total & 8.73 & 5.09 & 58.18 & 41.82 & \\
\hline
\end{tabular}

Table (10) showed that the highest difficulties that encountered the English student in cultural terms translation from English into Arabic were in items(13) and (10) with difficulties level (63.64) and (59.09) and the lowest were in items (3) and (4) with level (27.27) and (22.73) the total difficulties level was (41.82) which means that the level of problems and difficulties that encounter the English students at Palestinian universities in culture terms translation from English in to Arabicis high.

Results of $3^{\text {rd }}$ question "what is the level of problems and difficulties that encounter the English students at Palestinian universities in cultural sentences translation from Arabic in to English?The researcher calculate mean, standard deviation, relative weight, difficulties level, and rank in order to verify the problems and difficulties that encountered student in sentences translation from Arabic in to English as shown in table (11) 
Table (11) Means, standard deviation, relative weight, cultural sentences translation difficulties level from Arabic in to English

\begin{tabular}{|l|l|l|l|l|l|}
\hline No & Mean & $\begin{array}{l}\text { SD } \\
\text { deviation }\end{array}$ & $\begin{array}{l}\text { Relative } \\
\text { weight }\end{array}$ & $\begin{array}{l}\text { Difficulties } \\
\text { level }\end{array}$ & Rank \\
\hline $\mathbf{1 .}$ & 1.55 & 1.49 & 51.52 & 48.48 & 5 \\
\hline $\mathbf{2 .}$ & 1.27 & 1.47 & 42.42 & 57.58 & 3 \\
\hline $\mathbf{3 .}$ & 1.27 & 1.47 & 42.42 & 57.58 & 3 \\
\hline $\mathbf{4 .}$ & 1.14 & 1.44 & 37.88 & 62.12 & 2 \\
\hline $\mathbf{5 .}$ & 0.68 & 1.27 & 22.73 & 77.27 & 1 \\
\hline Total & 5.91 & 5.87 & 39.39 & 60.61 & \\
\hline
\end{tabular}

Table (11) showed that the highest problems encountered the student in translation sentences from Arabic into English was in item (5) with very high level (77.27) and the lowest in translation item (1) with high level (48.48) and the total level of difficulties was very high (60.61) which means that the level of problems and difficulties that encounter the English students at Palestinian universities in cultural sentences translation from Arabic in to English is very high.-Results of fourth question "what is the level of problems and difficulties that encounter the English students at Palestinian universities in culture sentences translation from English in to Arabic?The researcher calculate mean, standard deviation, relative weight, difficulties level, and rank for the $4^{\text {th }}$ question items and total score in order to verify the problems and difficulties that encountered student in sentences translation from English in to Arabic as shown in table (12)

Table (12) Means, standard deviation, relative weight, cultural sentencestranslation difficulties level from English in to Arabic

\begin{tabular}{|l|l|l|l|l|l|}
\hline No & Mean & $\begin{array}{l}\text { SD } \\
\text { deviation }\end{array}$ & $\begin{array}{l}\text { Relative } \\
\text { weight }\end{array}$ & $\begin{array}{l}\text { Difficulties } \\
\text { level }\end{array}$ & Rank \\
\hline $\mathbf{1}$ & 2.09 & 1.36 & 69.70 & 30.30 & 5 \\
\hline $\mathbf{2}$ & 1.82 & 1.45 & 60.61 & 39.39 & 4 \\
\hline $\mathbf{3}$ & 1.41 & 1.48 & 46.97 & 53.03 & 2 \\
\hline $\mathbf{4}$ & 1.27 & 1.47 & 42.42 & 57.58 & 1 \\
\hline $\mathbf{5}$ & 1.50 & 1.52 & 50.00 & 50.00 & 3 \\
\hline Total & 8.09 & 5.33 & 53.94 & 46.06 & \\
\hline
\end{tabular}

Table (12) showed that the highest problems and difficulties encountered the student in translation sentences from English into Arabic were in item (4) with very high level (57.58) and the lowest in translation item (1) with medium level (30.30) and the total level of difficulties was high (46.06)the level of problems and difficulties that encounter the English students at Palestinian universities in cultural sentences translation from English into Arabic is high.

\section{RECOMMENDATIONS}

The researcher recommends the followings-: 1-Simplifying of cultural translation for the students. 2Teaching and introducing all cultural translation difficulties and problems in details .3-Paying the attention for cultural, conceptual/semantic ,idiomatic and grammatical difficulties in cultural translation.4-Boosting and encouraging translating of different kinds of cultural subjects such as religious, social and political terms based on culture from English to Arabic and vice versa . 5-Adopting and composing courses for translating of different kinds of cultural translation such as concepts, terms and tenses used in culture for the students of the University, because as the researcher believes that variety and diversity are very important and they are considered a basic issue for the students of the University. Such course will introduce wide range of experience for the students. 6-Encouraging and boosting the students to write essays and paragraphs in law( in both languages) and discussing the committed errors in the essays and paragraphs with students to let the students be acquainted with their errors immediately after use. Such thing will improve the writing of the students and translation.7-Teaching the students the principles of cultural translating from English to Arabic and vice versa .8-Teaching the use all kinds of techniques of culturaltranslation. 9-Students must write English cultural composition according to English mentality and culture in order to avoid the interference of mother tongue i.e. Arabic Language .10-Teaching English language in comparison with Arabic language for the students of English Department at the university level . 11-Giving more attention for English style and Arabic style.12Teaching all aspects of cultural translation such as tenses, vocabulary, sentences ... etc.13-Teaching how to deal with the cultural context to understand the sentence or the context so as to carry out the translation accurately.14- Encouraging the students to consult with other people. 


\section{SUGGESTIONS FOR FURTHER RESEARCHES}

The researcher suggests the followings :-1-The researcher suggests carrying out researches on comparative studies between English/Arabic and Arabic /English cultural translation regarding difficulties, problems and solutions.2-Adopting researches on the function and aims of cultural translation.3-Carrying out researches about the interference and influence of Arabic language incultural translating from English to Arabic. 4-Carrying out researches about improving the cultural translation from English to Arabic and vice versa .

\section{REFERENCES}

[1] Mareş $\square$ - Lecturer, "DimitrieCantemir" Christian University,

[2] 2Bucharest- First Published In Europeana:2015-03-27- 1/20122-Delisle, J. (1988), Translation: An interpretive approach. University of Ottawa Press. Canada.

[3] Newmark, P. (1981), Approaches to translation. Language and teaching series. Pergamon. UK.

[4] Newmark, P.(1988), A textbook of translation. Prentice Hall. UK.

[5] Newmark, P. (1991), About translation. Multilingual Matters. UK.

[6] Newmark, P. (1993), Paragraphs on translation. Multilingual Matters. UK.

[7] Newmark, P. (1998), More paragraphs on translation. Multilingual Matters. UK.

[8] Newmark, P., et al (1999), Word, text, translation. Multilingual Matters. UK

[9] 9-Journal of Academic and Applied Studies (Special Issue on Applied Linguistics) Vol. 3(8) August 2013,

[10] pp. 13-21 Available online @ www.academians.org ISSN1925-931X 13

[11] The Role of Culture in Translation Monireh Akbari

[12] Hatim, B.,\& Mason, I. (1990).Discourse and the Translator. Longman: Longman Group Limited.

[13] Language Teaching December, 2008123 The Analysis of Cultural Gaps in Translation and Solutions Jianqing Wu

[14] Duranti, A. (1997). Linguistic anthropology. Cambridge: Cambridge University Press.

[15] Goodenough, W.H. (1981). Culture, language, and society. London: The Benjamin/Cummings Publishing Company.

[16] Newmark, P. (1988). Textbook of translation. Oxford: Pergamon Press.

[17] Newmark, P. (1981), Approaches to translation. Language and teaching series.Pergamon. UK.

[18] Vermeer, H.J. (2000). Skopos and commission in translational action. In L. Venuti (Ed.),The translation studies reader (pp. 221-232). London: Routledge.

[19] Ioana Irina DurdureanuTRANSLATION OF CULTURAL TERMS: POSSIBLE ORIMPOSSIBLE? July4 2011

[20] Dickins, J. (2000), Arabic. In Encyclopaedia of language teaching and learning.Byram, M. (ed.). Routledge. UK.

[21] Holman, M. and Boase-Beier, J. (1999), Writing, rewriting and translation through constraint to creativity. In The practices of literary translation: Constraints and creativity. Holman, M. (ed.). St. Jerome. UK.

[22] Sapir, E. (1949), Language and environment. In Selected writings of Edward Sapir in language, culture and personality. University of California Press. USA.

[23] Sapir, E. (1949), The status of linguistics as a science.Selected writings ofEdward Sapir in language, culture and personality. University of California Press. USA.

[24] Catford, J. (1965), A linguistic theory of translation. Oxford University Press. UK.

[25] Kussmaul, P. (1995), Training the translator. Benjamins. The Netherlands

[26] Nida, E. and Taber, R. (1969), The theory and practice of translation. Brill.Leiden

[27] The New Oxford Dictionary of English, Judy Pearsall, 1998.

[28] Ali Sulaimaan I. AddulaimiThe Impact of Culture on Translation, University of Tikreet, 2012

[29] Malinowiski, B. (1862): Sex, Culture, and Myth, London: Rubert Hart- Davis.

[30] Davis, K. (1977): Human Behavior at work, New York: McGraw-Hill Book Company.

[31] Haviland, W. (1975): Cultural Anthropology, New York: Rinehart and Winston.

[32] Aziz, Y. and Muftah,S.(2000): Principles of Translation, Benghazi: Dar Al-Kutub Al-Wataniyya.

[33] Newmark, P. (1988): Approaches to Translation, Cambridge: Cambridge University Press.

[34] Nida, E. (1985): "Translating Meaning", In: The 10th World Congress, Wein. Pp 121-9.

[35] Dulf, A. (1984): The Third Language, Pergamon Institute of English, pp 11-2.Completed on 27th May 2017 